\title{
The grant system of financing the South African local government sphere: Can sustainable local government be promoted?
}

\author{
M Oosthuizen and C Thornhill*
}

University of Pretoria, South Africa

\author{
* Corresponding author: C Thornhill, School of Public Management and Administration, University of Pretoria, Private bag \\ X20, Hatfield, Pretoria 0028, South Africa. \\ Email: chris.thornhill@up.ac.za
}

\begin{abstract}
Local government is considered to be government closest to the people. It is usually the third level or sphere of government in most countries. South Africa is divided into three spheres (not levels). Each sphere is distinctive yet interdependent and interrelated with the other spheres. The Constitution of the Republic of South Africa, 1996 provides for the allocation of functions and powers to each sphere, but prohibits one sphere of transgressing onto the area of jurisdiction of another sphere. The total geographic area of the country had been divided into three categories of municipality viz. category $A$ (metropolitan), category B (urban) and category C (district). The dilemma faced is that nearly $60 \%$ of the population is urbanised. Since the end of the apartheid government's era municipalities were merged into non-racial municipalities including large rural areas comprising relatively poor communities which cannot make any or only a limited financial contribution for the services they receive. The result is that municipalities have to rely on grants from the national government to provide basic services such as water, electricity, refuse removal and sanitation. The article addresses the justification for the allocation of grants to the various categories of municipality. It then explains the various kinds of grants and attends to the question of whether municipalities could provide sustainable services if they have to rely on grants. The article is mainly a desktop research project relying on documentation from official reports from, e.g. the Auditor-General and National Treasury, relevant legislation, other policy documents and literature were also consulted. A qualitative research approach is followed.
\end{abstract}

\section{Keywords}

constitution, grant, local government, municipality, recurrent grant, specific grant, sphere sustainability, system 


\section{Introduction}

With the adoption of The Constitution of the Republic of South Africa, 1996, the country's municipalities became one of the three spheres of government. It is entrenched in the Constitution - mandated to deliver basic services as well as to be developmental by contributing to the economic and social development of the communities in each of the municipalities as constituent units. Segregation laws and apartheid-based local government by the former government left large rural areas without basic services and infrastructure development. This led to numerous laws and policies being put in place by the new democratic government elected in 1994 to support municipalities to access the required funds to contribute to government's developmental goals and to achieve its service delivery objectives.

Equitable distribution of nationally raised revenue by means of a grant system was introduced by national government to enable under-resourced municipalities to address service delivery and infrastructure backlogs and to assist larger municipalities to maintain and enhance its service delivery to communities. Most studies show that for municipalities to be sustainable it must have sound financial management systems in place and must be able to collect and effectively use its own revenue to meet its service delivery obligations in continuously. It also entails being able to utilise grant funding to augment its own revenue sources efficiently and effectively to create new infrastructure and to maintain it.

The grant system could lead to a permanent dependency of municipalities on national funding instead of ensuring the independence and sustainability of the local sphere of government through locally based revenue sources. The Division of Revenue Act, 3 of 2016 provides, for example, for recurrent grants totalling R 1. 74 billion ( $£ 1=\mathrm{R} 16$ ) (Act 3 of 2016, schedule 5, Part B) and specific purpose grants totalling R28.01 billion ( $£=R 16$ ) (Act 3 of 2016 , schedule 5, Part B). It is also doubtful whether municipalities have the necessary capacity and skills to utilise grant funding to sustain service delivery, to create new infrastructure and to maintain infrastructure already constructed.

The article explains the grant system of financing the local sphere of government and investigates whether it promotes sustainable municipal service delivery. The sources of municipal revenue will be investigated, the principles of the grant system and the various types explained, and the mechanisms to demand accountability for the allocated grants will be discussed to establish whether the system does indeed contribute to sustainable service delivery and promote developmental local government.

\section{Objects, functions and obligations of municipalities}

The Constitution of the Republic of South Africa, 1996 (Constitution) forms the legal and administrative basis for the municipalities. According to section 151(3) of the Constitution a municipality has the right to govern the local government affairs of its community on its own initiative, subject to national and provincial legislation. Section 153 provides for the developmental duties of municipalities. Municipalities must structure and manage their administration as well as budgeting and planning processes to give priority to the basic needs of the community and to promote their social and economic development. Thornhill and Cloete (2014: 21) define developmental as an active role that municipalities play in promoting development in cooperation with the community and 'not merely manage the developmental process'.

Section 152 of the Constitution, 1996, states that the objects of municipalities include the provision of democratic and accountable government for local communities, the provision of 
services to communities in a sustainable manner, the promotion of social and economic development and a safe and healthy environment, and the involvement of communities and community organisations in the matters of local government. An important aspect is the requirement that municipalities must strive to achieve these objectives within their financial and administrative capacity.

The duty of local government to ensure the provision of services to its communities in a sustainable manner is provided for in the White Paper on Local Government, 1998 (White Paper). It underlines the local government developmental outcomes such as the provision of household infrastructure and services; creating integrated cities, towns and rural areas; the promotion of local economic development; and community empowerment and redistribution. It also includes finding sustainable ways to meet the needs of the communities and improve their quality of life (South Africa, Republic, 1998a: 10).

The Local Government: Municipal Systems Act, 32 of 2000 (MSysA) provides for the general duties of a municipality. Section 73 compels a municipality to give priority to the basic needs of the community, to promote the development of the community and to ensure that all members of the local community have access to at least the minimum levels of basic municipal services. These services must be provided in a way that contributes to the economic, efficient and effective use of resources; be financially sustainable and be regularly reviewed to ensure upgrading, extension and improvement.

Further to this the MSysA states in its preamble that the system of local government under the policy of apartheid of the former government that divided society into racial groups 'failed dismally to meet the basic needs of the majority of South Africans'. Therefore, a need exists to empower municipalities to promote social and economic upliftment of communities in addition to the provision of basic services to all the people, especially the poor and disadvantaged. The new system of local government which was introduced with the first democratic municipal elections in 2000 requires an efficient, effective and transparent local administration and financially and economically viable municipalities.

Based on the legislative framework as indicated above it is clear that municipalities have an obligation to ensure sustainability in the delivery of services, to provide and maintain the necessary infrastructure, to be accountable and to ensure sound management of municipal finance.

\section{Sustainable local government}

South Africa's national vision for sustainable development includes meeting the essential human needs of the people of the country by promoting amongst others, efficient and effective integrated planning and governance through national, regional and global cooperation (Department of Environmental Affairs, South Africa, Republic, s.a.: 2). Thornhill et al. (2013: 136) define sustainable development as development that meets the needs of the current generation without jeopardising the ability of future generations to meet their own needs.

Madonsela (2013: 7) describes sustainability as 'uninterrupted, seamless provision of quality services to the people', as well as service that is 'forever improving' and that would eventually lead to the ability of people to be independent - to meet their own basic needs and rely less on the state. Independence is clarified by Thornhill (2011: 48) stating that one of the most important requirements to be independent is financial self-sufficiency and being able to meet the demands of society by means of funds generated from own resources.

In support of the above, an investigative report initiated by the South African Minister of Finance in 2013 regarding the use of infrastructure grants by municipalities states that the 
sustainability of local government is closely related to the investment in infrastructure. Although this can be regarded as diverting funds from government's main aim to eradicate backlogs in poor municipalities 'targeted economic infrastructure can often do more to transform the lives of a municipality's indigent population by creating development opportunities' (South Africa, Republic, 2014c: 10).

\section{Municipal revenue}

Section 229 of the Constitution, 1996, assigns municipalities the authority to raise its own revenue by means of property rates and surcharges for services (e.g. water, sanitation, waste removal and electricity, and the use of municipal facilities such as sports grounds). A municipality may not impose income tax, value-added tax, general sales tax or customs duty (Thornhill and Cloete, 2014: 104). The Municipal Fiscal Powers and Functions Act, 12 of 2007 (MFPFA) defines surcharges as charges in excess of the municipal base tariff that a municipality may impose on fees for a municipal service provided by or on behalf of a municipality.

A municipality must ensure that its customers are billed; that it collects all money due and payable to it; and that it adopts, maintains and implements a credit control and debt collection policy. These activities must be in line with its rates and tariff policies provided for in sections 95 and 96 of the MSysA.

The ability to raise own revenue to finance the functions that are allocated to them differs radically across municipalities. Poor rural municipalities receive most of their revenue from grants through the annual Division of Revenue Act (DoRA), while urban municipalities raise the major part of their revenue from own sources (South Africa, Republic, 2015a: 30). Poor and rural municipalities rely heavily on national transfers through various forms of grants since they have significant lower tax bases than large cities. Therefore, government allocates larger portions of the available equitable share allocated through the annual DoRA to poor and rural municipalities, while urban municipalities are urged to use their own resources to increase investment in infrastructure (South Africa, Republic, 2016b: 74).

Mahabir and Mabena (2015: 1) state that it is to be expected that gaps in available funds will result when the cost to address the needs or demands of local communities exceeds the revenue generated by municipalities. This gap is the main reason for intergovernmental transfers through grants to municipalities, mostly in the form of infrastructure conditional grants and also unconditional grants. The above-mentioned authors maintain that the aim of these grants addresses financial shortcomings at municipalities, supports the strategic priority of government to eradicate service delivery backlogs and contributes to local economic development in the country.

\section{Financing municipalities}

Section 213 of the Constitution, 1996, provides for the establishment of a National Revenue Fund. Section 214(1)(a) states that an Act of Parliament must provide for the equitable division of revenue that is raised annually amongst the national, provincial and local spheres of government. To comply with section 214 of the Constitution, the DoRA is passed by Parliament annually. It provides for the budgeting for allocations to national government, the nine provinces and current 257 municipalities through grants. The purpose of these grants is to enable municipalities to provide basic services and perform the functions allocated to it (Section 227, Constitution, 1996).

The MFPFA defines municipal service as any of the local government matters listed in 
Schedule 4B and Schedule 5B of the Constitution, 1996. These include all the services assigned to this sphere of government, e.g. health services, building regulations, firefighting services, transport, water and sanitation, streetlights and public spaces.

\section{Rationale for revenue sharing}

The 1998 White Paper ascribes the inability of local government in South Africa to perform its functions effectively to the apartheid era that led to spatial separation of people and the disregard for development and municipal services in rural areas. It maintains that this forms the basis of the numerous problems the new local government system has to overcome. The 1998 White Paper preceded the adoption of the Local Government Transition Act, 209 of 1993, that provided a framework for transformation to a new local government system in South Africa and highlights that transformation ultimately rests with each municipality. This required every municipality to integrate the services previously assigned separately to White, Coloured, Indian and Black local authorities in a particular geographical area.

The 1998 White Paper further states that national government will support and enable the local government transformation process by amongst others creating an enabling legal framework; decentralising powers and functions to local government; supporting improved service delivery by means of capacity-building, capital funding and hands-on assistance; introducing the equitable share by the national fiscus to which local government is constitutionally entitled; and working with all stakeholders who can contribute to building municipal sustainability (South Africa, Republic, 1998a: 208-211).

Aligning to the broad vision in the 1998 White Paper, the government's National Development Plan (NDP) provides for a long-term strategic plan for the country until 2030, aiming at the elimination of poverty and inequality to ensure that all South Africans have a decent standard of living (National Development Plan, 2011: 14-16). Incorporated in the NDP is a National Infrastructure Development Plan containing various initiatives to eradicate unemployment and to improve the delivery of basic services. Within this government programme, integrated municipal infrastructure projects include the development of municipalities with the least resources, focusing on the backlogs in maintain existing infrastructure as well as upgrades required in water and electricity provision, bulk infrastructure and roads (KPMG, 2014: v).

The South African Local Government Association (SALGA) maintains that the main reason for the establishment of an equitable share derived from revenue collected nationally and distributed among the three spheres of government is to ensure that the poor continue to be protected against the effects of unemployment, poverty and inequality. The division of an equitable share enables municipalities to provide basic services (identified as water, electricity, refuse removal and sanitation) to poor households and supports municipalities with limited own resources to perform core municipal functions (SALGA, 2015a: v).

\section{Division of revenue among spheres of government}

Numerous pieces of legislation enact the division of revenue. The DoRA forms an important link in the South African fiscal system. It is passed annually and provides for the 'equitable sharing of nationally raised revenue between national, provincial and local spheres of government'. It also spells out the responsibilities of the different spheres of government on the utilisation of the allocated funds (SALGA, 2011: 1).

Parliament passes a DoRA since the 1998/99 financial year. It is amended every year in line 
with the development of financial policies for each Medium Term Expenditure Framework (MTEF). The MTEF covers a three-year period to ensure predictability and stability in local government finances (SALGA, 2011: 1).

Section 10(1) of the Intergovernmental Fiscal Relations Act, 97 of 1997 (IFRA), requires the Minister of Finance to introduce a Division of Revenue Bill in the National Assembly on the same day that the Annual Budget is delivered. When adopted it becomes the DoRA. The IFRA prescribes the process for determining the equitable sharing and allocation of nationally raised revenue. Sections 9 and 10(4) of the Act set out the consultation process to be followed with the Financial and Fiscal Commission (FFC). This process requires considering recommendations made for the division of revenue. The FFC is an independent public body, established by law that makes recommendation to Parliament on the equitable division of revenue between the three spheres of government and provide advice to organs of state on financial matters (www.ffc.gov.za).

Section 10(5) of the IFRA requires that an explanatory memorandum accompanies the annual DoRA, indicating amongst others how the matters listed in sections 214(2)(a) to (j) of the Constitution, 1996, were considered in the fund distribution among provinces and municipalities (South Africa, Republic, 2015b: 1). The matters listed in the Constitution, 1996 include national interest; provision for debt; the need to ensure that provinces and municipalities are able to provide basic services and perform functions allocated to them; the fiscal capacity and efficiency of provincial and local government; developmental and other needs of provinces, local government; economic disparities; and the desirability of stable and predictable allocations of revenue shared among the municipalities. Each municipality must utilise each specific grant and allocation in accordance with the terms of the grant framework (SALGA, 2011: 1).

The objects of the DoRA are set out in Section 2(a) of the Act. It includes the equitable division of revenue raised nationally between the three spheres of government; the determination of each province's equitable share of the provincial share of that revenue; other allocations to provinces, local government or specific municipalities from the national government's share of that revenue and conditions applying to the allocations. It further entails the promotion, predictability and certainty in respect of all allocations to provinces and municipalities. This ensures that provinces and municipalities can plan their budgets over a multi-year period. It promotes better coordination between policy, planning and budgeting. The DoRA also promotes transparency and accountability in the resource allocation process by ensuring that allocations are reflected on the budgets of provinces and municipalities and the expenditure based on the conditional grants is reported by the receiving provincial departments and municipalities.

Section 214 of the Constitution, 1996 requires that the annual DoRA be passed after factors contained in subsections (2) (a) to (j) of the Constitution, 1996 are taken into account. The Money Bills Amendment Procedures and Related Matters Act, 9 of 2009, requires the Minister of Finance to publish a Division of Revenue Amendment Act if the national adjustments budget necessitates changes to the DoRA of the relevant financial year (SALGA, 2011: 3).

\section{Determining the allocation of funds}

In the Explanatory Memorandum to the DoRA, 2015, it is stated that the mechanisms for allocating funds to provinces and municipalities are continuously reviewed to improve its efficiency. 'To maximise the effect of allocations, many provincial and local government conditional grants use criteria that consider the efficiency with which the recipient has used previous allocations' (South Africa, Republic, 2015b: 3). 
Equitable shares are determined by formulas that take into account demographic and developmental aspects of each province or municipality (South Africa, Republic, 2016b: 74). Treasury further maintains that these equitable share formulas are used when determining developmental needs and when allocating specific conditional grants such as the Municipal Infrastructure Grant (MIG). These grants are allocated to municipalities according to the number of households without access to basic services (South Africa, Republic, 2015b: 3). For the 2015 MTEF, the MIG allocation formula uses data from the 2011 Census. Allocations for basic services are based on the proportion of the national backlog for that service in each municipality. It also considers the proportion of the country's poor households located in individual municipalities. Examples of conditional grants provided on the basis of specific formulas are (South Africa, Republic, 2015b: 42-44) as follows:

- the Municipal Urban Settlements Development Grant which is a supplementary grant that should be used by the eight metropolitan municipalities, respectively, in accordance with their peculiar needs to provide infrastructure for municipal services and upgrade urban informal settlements;

- the Municipal Water Infrastructure Grant to fast track the delivery of clean water to communities without access to basic water services;

- the Rural Households Infrastructure Grant provides for sanitation services for rural households where piped infrastructure is not possible;

- the National Electrification Programme Grant provides for the funding of electricity to indigent households; and

- the Capacity-Building Grant is aimed at developing skills for management, planning, technical, budgeting and financial matters in municipalities.

The Explanatory Memorandum to the DoRA, 2015 (South Africa, Republic, 2015b: 30) claims that with regards to allocation there is an emphasis on basic services that align with the back-tobasics approach to local government announced by the Minister of Cooperative Governance and Traditional Affairs in 2014; and that the 'local government fiscal framework as a whole including all transfers and own revenues - is structured to support the achievement of the NDP's goals'. This is emphasised by the Medium-term Strategic Framework (MTSF) 2014-2019 which is Government's strategic plan for the 2014-2019 municipal electoral term and 'reflects the commitments made in the election manifesto of the governing party'. This includes the commitment to implement the NDP goals of, inter alia, development, growth and addressing poverty and inequality. The MTSF describes the actions government plans to take and the targets it intends to achieve and 'provides a framework for prioritising and sequencing government programmes and development initiatives for the next five years' (South Africa, Republic, 2014e: 4-5).

The back-to-basics plan (to be explained later) of the Department of Cooperative Governance and Traditional Affairs (COGTA) provides clear directives for local government sustainability. It identifies the poor record of service delivery in providing the basic services such as refuse collection, fixing of potholes, maintaining public places and repairing streetlights. The lack of capacity in municipalities to perform these functions is raised, as well as the fact that the lower performing third of the current 257 municipalities, (according to financial performance) are dysfunctional. Corruption, poor engagement with communities, poor financial management and negative audit outcomes must be addressed. The approach is aimed at supporting municipalities 'to progress towards a higher path' and to provide those municipalities who perform well, with 
more control over allocated grants (South Africa, Republic, 2014b: 7-8).

It is evident that the allocation of fund transfers in the form of grants to municipalities is largely determined by government's strategic development priorities and previous performance results of municipalities. National government indicates that it would allocate more than R112 billion ( $£ 1=\mathrm{R} 16$ ) of the equitable share to local government in the 2016/17 financial year, as indicated in Table 1.

Table 2 shows that $65 \%$ of the nationally collected revenue is allocated to national government, $31 \%$ to provincial government and $4 \%$ to local government. It must be emphasised that the equitable share also indicates the estimates for the following two financial years to provide certainty in municipal budgeting.

\section{Grants}

Mahabir and Mabena (2015: 249) identify two forms of intergovernmental fund transfers, namely general purpose (i.e. unconditional) and specific purpose (i.e. conditional). 'Although unconditional and conditional grants can be used for funding both operating and capital expenditure, in most cases capital expenditure is funded through conditional grants'.

SALGA maintains that conditional grants are allocated either as direct or indirect transfers to municipalities. With direct transfers, funds are paid directly into the primary bank account of a municipality. These funds must be reflected in the municipality's approved budget. To access these grants municipalities are compelled to submit business plans to the national transferring departments and must report on the financial and non-financial outcomes associated with these grants (SALGA, 2011: 3-4). For example in the 2015/2016 financial year the following grants were allocated to municipalities (DoRA, 3 of 2016, schedule 5 part B)

\section{Recurrent grants}

- Urban Settlements Development Grant (From the Department of Human Settlements vote 38);

- Integrated City Development Grant (From National Treasury's vote 7);

- Municipal Demarcation Transition Grant (From the Department of Cooperative Governance and Traditional Affairs, vote 4);

- Energy Efficiency and Demand Side Management Grant (From National Treasury, vote 7);

- Expanded Public Works Programme, Integrated Grant for Municipalities (Public Works, vote 11)

\section{Specific purpose allocations}

- Infrastructure Grants (including disaster recovery grant, MIG, municipal systems improvement,integrated national electrification programme (municipal) grant, neighbourhood development partnership grant, rural roads asset management systems grant, water services infrastructure grant and regional bulk infrastructure grant(various votes).

Indirect transfers relate to funds that are paid to a public entity or a national department to deliver services on its behalf where municipalities do not have the required capacity (SALGA, 2011: 3-4). In its briefing on the submission for the 2016/17 division of revenue, the FFC states 
Table 1. 2016 Summary of allocation of equitable share to local government.

\begin{tabular}{|c|c|c|c|}
\hline Summary & $\begin{array}{l}2016 / 17 R \\
\text { thousands }\end{array}$ & $\begin{array}{l}2017 / 18 R \\
\text { thousands }\end{array}$ & $\begin{array}{l}2018 / 19 R \\
\text { thousands }\end{array}$ \\
\hline \multicolumn{4}{|l|}{ Direct transfers } \\
\hline Equitable share and related & $52,568,706$ & $57,012,141$ & $61,731,845$ \\
\hline Fuel levy sharing & $11,223,830$ & $11,785,023$ & $12,468,554$ \\
\hline Infrastructure & $39,119,734$ & $42,268.124$ & $44,787,086$ \\
\hline Municipal infrastructure grant & $14,914,028$ & $15,691,252$ & $16,593,685$ \\
\hline Urban settlement development grant & $10,839,468$ & $11,472,247$ & $12,052,137$ \\
\hline Public transport network grant & $5,592,691$ & $6,359,895$ & $6,793,269$ \\
\hline Integrated national electrification programme grant & $1,946,246$ & $2,087,048$ & $2,204,477$ \\
\hline Neighbourhood development partnership grant & 624,000 & 663,390 & 701,867 \\
\hline Rural roads assets management systems grant & 101,514 & 101,309 & 113,533 \\
\hline Regional bulk infrastructure grant & $1,850,000$ & $1,865,000$ & $2,060,000$ \\
\hline Water services infrastructure grant & $2,844,982$ & $3,729,864$ & $3,959,056$ \\
\hline Integrated city development grant & 266,805 & 292,119 & 309,062 \\
\hline Municipal disaster recovery grant Capacity building and & 14,000 & & \\
\hline other current transfers & $1,742,773$ & 957,872 & 895,085 \\
\hline Local government financial management grant & 465,264 & 502,006 & 531,122 \\
\hline Expanded public works programme integrated grant & 663,991 & & \\
\hline Infrastructure skills development grant & 130,471 & 140,774 & 148,939 \\
\hline Energy efficiency and demand side management grant & 185,625 & 203,236 & 215,024 \\
\hline \multicolumn{4}{|l|}{ Municipal disaster grant } \\
\hline Municipal demarcation transition grant & 297,422 & 111,856 & \\
\hline Unallocated & 269,000 & $1,316,708$ & $1,428,576$ \\
\hline Subtotal direct transfers & $104,924,043$ & $113,339,868$ & $121,311,146$ \\
\hline Indirect transfers & $7,688,917$ & $7,297,299$ & $7,564,002$ \\
\hline Infrastructure transfers & $7,688,917$ & $7,297,299$ & $75,643,002$ \\
\hline Regional bulk infrastructure grant & $3,478,829$ & $2,806,279$ & $2,931,443$ \\
\hline $\begin{array}{l}\text { Integrated national electrification } \\
\text { programme (Eskom) grant }\end{array}$ & $3,526,334$ & $3,876,154$ & $3,995,031$ \\
\hline $\begin{array}{l}\text { Neighbourhood development partnership } \\
\text { grant (technical) }\end{array}$ & 22,209 & 27,744 & 29,363 \\
\hline Water services infrastructure grant & 311,545 & 587,122 & 608,175 \\
\hline Bucket eradication programme grant Capacity building and & 350,000 & & \\
\hline other current transfers & 84,349 & 103,249 & 115,116 \\
\hline Municipal systems improvement grant & 84,349 & 103,249 & 115,116 \\
\hline Subtotal indirect transfers & $7,773,266$ & $7,400,548$ & $7,679,118$ \\
\hline Total & $112,697,309$ & $120,740,416$ & $128,990,264$ \\
\hline
\end{tabular}

Source: Adapted from South Africa. National Treasury (2016c). Annexure: Summary of allocation to Local Government (www.treasury.gov.za).

The division of the revenue collected nationally and distributed among the three spheres is presented in Table 2 (DoRA, 3 of 2016). 
Table 2. Equitable share to spheres of government.

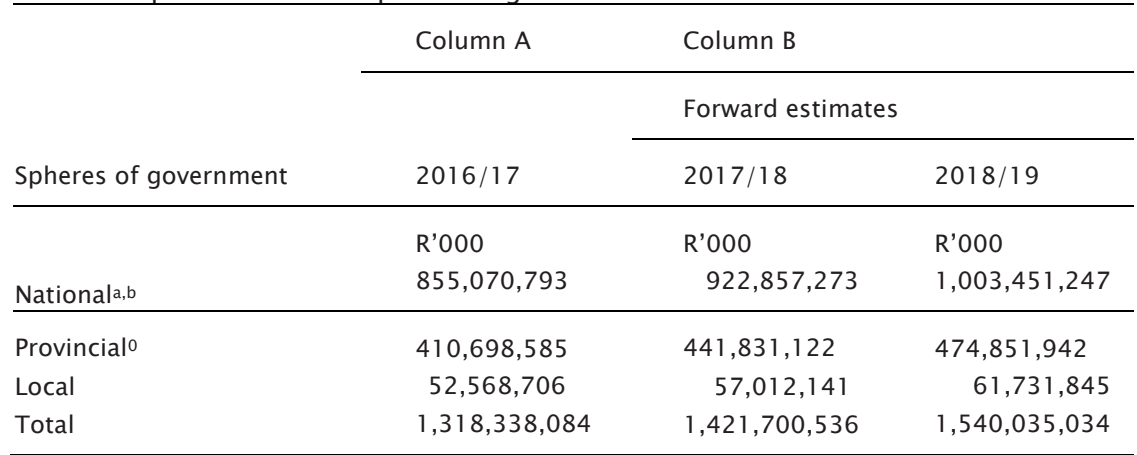

Division of Revenue Act 3 of 2016.

aNational share includes conditional allocations to provincial and local spheres, general fuel levy sharing with metropolitan municipalities, debt service costs and the contingency reserve. ${ }^{\mathrm{b}}$ The direct charges for the provincial equitable share are netted out.

Provincial share includes an unallocated amount of R5.8 billion in 2018/19 that is not included in the forward estimates of provincial allocations. 
that indirect grants that drive infrastructure development are characterised by widespread under spending (South Africa, Republic, 2015b: 16). This trend indicates that municipalities often lack the capacity to utilise the funds and consequently do not provide the services they are expected to deliver to their respective communities. To assist municipalities the following grants are also made:

Allocations-in-kind to municipalities for designated special programmes (DoRA, 2016 schedule 6, Part B)

- Integrated National Electrification Programme (Eskom) Grant (Department Energy vote 26);

- Neighbourhood Development Partnership Grant (National Treasury, vote 26);

- Bucket Eradication Programme Grant (Department Water and Sanitation, vote 36);

- Water Services Infrastructure Grant (Department Water and Sanitation, vote 36); and

- Regional Infrastructure Grant (Department Water and Sanitation, vote 36).

These grants are targeting specific municipalities requiring financial assistance for the installation and maintenance of infrastructure not covered by the other grants mentioned above.

\section{Oversight and accountability regarding grants}

The Local Government: Municipal Finance Management Act, 56 of 2003 (MFMA) (Section 3840) allows National Treasury to discontinue the equitable share allocation if there is persistent and serious noncompliance with the DoRA. Section 38 states that if the allocation of funds is discontinued and it affects the provision of basic services, the provincial executive must monitor the continuation of those services. Similarly, section 216 of the Constitution, 1996, allows National Treasury to discontinue transfers to municipalities in the event of serious or continuous non-compliance with measures specified in the Constitution, for example non-payment of debt to service providers like Eskom and Water Boards within the legislated 30-day timeframe (South Africa, Republic, 2015b: 5). Eskom (s.a.: v) is a state-owned enterprise that generates approximately $95 \%$ of the electricity used in South Africa while the main function of the nine water boards in South Africa is to provide water services, namely bulk potable and bulk waste water to otherwater service institutions in their areas of operation (South African Government, 2014e: v). Section 3 of the DoRA, 2016 states that if National Treasury anticipates substantial underspending or overspending on the allocation it may stop the funding or a part thereof.

Ultimately the MFMA places the responsibility for sound and sustainable management of its financial affairs on each municipality by requiring amongst others transparency, accountability, approval and management of its annual budgets. Further to this the Auditor-General (appointed in terms of Section 188 of the Constitution, 1996) is mandated to annually audit the financial affairs of municipalities by examining performance information and compliance with all laws and regulations governing municipal financial matters (South Africa, Republic, sa.: 2).

National departments must report to Parliament regarding the outcomes of grants appropriated for a specific purpose. Therefore, when funds are transferred directly to the bank account of a municipality, it can be accessed after submission of business plans to the transferring national department. Municipalities must report on financial and non-financial outcomes of the grants to COGTA.

In the local sphere of government, the local electorate should hold municipalities and councillors to account regarding achievements with grant allocations (South Africa, Republic, 
2014c: 7). Government's back-to-basics report states that municipal councils must exercise oversight over the administration of the departments and entities for which they are accountable. Citizens must have mechanisms and forums available to hold councillors accountable for the promises they made during the electoral process. It adds that regular national citizen satisfaction surveys will be held and that government will assist municipalities to develop community engagement plans (South Africa, Republic, 2014b: 9).

Each municipality is compelled by section 25 of the MSysA to develop an Integrated Development Plan (IDP) that entails an assessment of the current level of development and the identification of its key development priorities which must include communities within their areas of jurisdiction without access to basic municipal services. Section 26(d) of the MSysA states that the development strategies of the municipal council must be in line with national and provincial sectoral plans and planning requirements that are compulsory. The IDP must include a financial plan with a budget projection for at least three years and have clear performance indicators and performance targets.

The importance of the IDP is that it identifies the poorest areas and those without services and consequently it directs municipal spending. It enhances implementation because of compulsory stakeholder participation. 'The IDP provides deadlock-breaking mechanisms to ensure that projects and programmes are efficiently implemented' and 'assists to develop realistic project proposals based on the availability of resources' (www.etu.org.za/toolbox/docs/localgov/). The MSysA requires that the IDP be developed as a five-year plan and assigns the municipal manager as head of administration the responsibility for the implementation and monitoring of the IDP process. This Plan naturally requires funding. The challenge is to ensure that a municipality has adequate financial and other sources to implement the Plan during its five-year term. Thus, it also raises the issue of the sustainability of municipalities to honour their 'promises' as contained in the IDP.

\section{Sustainability}

The MTSF 2014-2019 affirms that although basic services have been extended to larger numbers of households, municipal performance does not meet the expected standards. The installation of, e.g. water infrastructure does not guarantee that potable water will be available on a continuous basis. Sustainability of services is threatened by neglect of routine maintenance and although service delivery backlogs are being addressed there are critical challenges related to rapid urbanisation and in-migration that should be addressed. Migration to one of the metropolitan municipalities (Tshwane) is estimated at 10,000 per month. Other serious challenges for municipalities include deteriorating public trust; the lack of municipal capacity to manage its resources and maintain basic services and to collect revenue (municipalities collect on average only about $68 \%$ of the revenue they are entitled to); "weak leadership and political interference in operations, poor financial management; lack of transparency and accountability; and weak and ineffective platforms for public participation and communication with communities' (South Africa, Republic, 2014e: 27).

The likelihood of municipal service delivery improving is very low since $60 \%$ of the municipalities are in financial distress. This leads to poor service delivery and increasing service delivery protests. This was revealed by Ratings Afrika in its analysis of the 2014/15 annual financial statements (as well as in the four previous financial years) of the 100 largest municipalities in the country (Slabbert, 2016: 1-3). Ratings Afrika is a ratings agency that specialises in ratings and opinions to measure the soundness of governance in the different 
spheres of government (www.ratingsafrika.com). The rating reveals that two metropolitan municipalities with the biggest household income, namely the City of Johannesburg and the City of Tshwane have the lowest financial sustainability due to shortcomings in their budgetary practices and financial discipline. It questions the 'soundness of governance processes by councils who are the guardians of public funds as well as the efficiency of oversight by provincial and national treasuries' (Slabbert, 2016: 2). Other issues raised, include that the worst performing municipalities are in the Free State Province and North West Province where alternatively 25 and 26 municipalities have massive cash shortfalls and are 'probably commercially insolvent'.

The FFC states that municipal infrastructure-related spending forms a substantial part of the total local government expenditures - averaging almost $60 \%$ since 2006. It questions the effectiveness of this capital spending by municipalities in view of continuous service delivery challenges that municipalities are faced with (South Africa, Republic, 2015a: 8-12).

The Minister of Police stated in the South African Police Department Budget Vote 2015/16 that South Africa is experiencing an alarming increase in community protests of which a major number are reportedly due to lack of service delivery or non-sustainable service delivery. In 2014/15 the South African Police Services (SAPS) reacted to 14,740 incidents of which 12,451 were peaceful and 2289 became violent (Nhleko, 2015: v). Service delivery states that these service delivery protests must be recognised as a serious condemnation by the community of the ability of local government to serve the people of the country satisfactorily.

According to the 2013-14 audit report on local government (South Africa, Republic, 2014a: 7) only $40(4 \%)$ of municipalities in South Africa received a clean audit. A major concern is the weakness of municipalities in the effective utilisation of grants which had been a repetitive theme in the Auditor-General's reports for the past few years (South Africa, Republic, 2014a: 10). The report stated that $26 \%$ of the municipalities that received grants did not comply within the reporting period. These include 27 municipalities (10\%) that used grant allocations for commitments other than that specified in the DoRA and 51 (19\%) that did not implement the programmes funded by the allocations.

Another concern is the extent to which the planned targets for grants were not reached. A total of $43 \%$ of the municipalities that received MIGs allocations did not achieve their planned targets. Reasons provided by these municipalities for their weak management of grant funding include poor planning and project management, insufficient capacity to deliver on the projects that were funded and using grants for purposes other than those intended (South Africa, Republic, 2014a: 10).

A task team initiated by the Minister of Finance in 2013 to review the MIG system states that sustainability of municipalities depends on their capacity to manage grant-funded infrastructure. It was highlighted that although the main aim of capital grants is to create assets, municipalities do not have the ability to sustainably manage it after its completion (South Africa, Republic, 2014c: 8). Despite the fact that the importance to maintain infrastructure is constantly highlighted, municipal officials reported that emergency repairs are prioritised while preventative maintenance that would have circumvented the emergency is neglected. This underspending by municipalities on maintenance is mainly due to pressure from politicians to address other short-term needs (South Africa, Republic, 2014c: 36). It is also emphasised that although the local electorate is supposed to hold municipalities and politicians accountable regarding achievements with grant funding, it is largely absent (South Africa, Republic, 2014c: 7). This lack of enforcing accountability could to a large extent be ascribed to the party political system that pervades the South African municipal scene.

The Constitution, 1996 provides for three categories of municipalities. The Local Government: 
Municipal Structures Act, 117 of 1998 contains the criteria that determine when an area must have a category A municipality (metropolitan municipality) and when municipalities fall into category B (local municipality) or C (district municipality). District municipalities have legislative and executive authority in areas that include more than one (local) municipality. With regards to the dependence of municipalities on grant funding and the failure of municipalities to raise its own revenue, Palmer (2011: 11) maintains that few of the country's district municipalities have the capacity to raise their own revenue by means of services that they provide and 'have become largely grant funded bodies relying on transfers for $90 \%$ of their revenue'. They cost the state 'a considerable amount of money' and underspend on their MIG allocations as referred to above.

This statement is supported by Schoeman (2011: 2) who maintains that fiscal sustainability in the local sphere of government is a reason for concern. The author emphasises the fact that municipalities must enhance their performance with regards to their revenue collection from own sources. While almost half of South African municipalities finance more than 50 per cent of their current expenditures by means of own revenue, almost one-third is dependent on grants from national and provincial government. It is further stated that municipalities have a historic dependence on grants to finance not only capital expenditure but also current expenditure.

The FFC maintains that municipalities do not take responsibility for their own performance when using indirect grants since it is not their own revenue being utilised. Although national departments responsible for these grants have to account to Parliament, and Parliament in turn accounts to the electorate, this long accountability loop is often ineffective and results in the wrong role players being held responsible for spending inefficiencies (South Africa, Republic, 2015a: 18-19). The Commission revealed that by February 2015 municipalities owed almost R9.5 billion ( $£ 1=\mathrm{R} 16)$ to Eskom, the bulk electricity provider. The municipalities in three of the provinces (Mpumalanga, Free State and North West) are responsible for $82 \%$ of the outstanding amount while municipalities owed R3.6 billion $(£ 1=\mathrm{R} 16)$ to various Water Boards providing bulk water to municipalities. This resulted in the Local Government Equitable Share being withheld from 59 municipalities (South Africa, Republic, 2015b: 5-10) with dire consequences for the communities affected.

An example of the concerns raised regarding sustainable service delivery is the Bushbuckridge Local Municipality. When the President of South Africa, Mr Jacob Zuma visited the Municipality in 2015 he noted that $70 \%$ of the community do not even have access to bulk water supply while $75 \%$ of residents do not have a water connection on their property and rely on borehole water. The community also expressed their discontent with the poor condition of roads, delays in the processing of social grant applications, the abuse of foster care grants and contractors who failed to complete housing projects (Evans, 2015: v).

In 2012, National Treasury discontinued a grant allocation to a municipality for the first time when it cut off transfers to Nala Local Municipality (Category B) in the Free State Province. It stated that the Municipality has repeatedly failed to submit financial statements and that the decision came after a number of years of giving the Municipality time to address the situation. Transgressions included maladministration, mismanagement, corruption and fraud dating back to the 2008/ 09 Audit Report of the Auditor-General. National Treasury reports that although its decision will affect service delivery and employee salaries, it is meant to send a 'strong message' that maladministration, financial mismanagement, corruption and fraud will not be condoned at the expense of transparency and accountability (Clark, 2012: v).

Some municipalities claim to be successful with the implementation of grants received. Mogale City Local Municipality maintains in its 2016 State of the City Address that it received two clean audits from the Auditor- General in successive financial years. It lists numerous 
successful programmes, for example its MIG multi-year road construction programme for the Western Rural Areas where R158.5 million ( $£ 1=\mathrm{R} 18)$ was spent on road and storm water construction in the City over the past five years of which infrastructure for rural areas accounted for R58.3 million ( $£ 1=\mathrm{R} 18$ ) (Seerane, 2016: [v]).

Despite its poor performance results by Ratings Afrika (www.ratingsafrika.com) the executive mayor of the Metropolitan City of Tshwane in the Gauteng Province asserts in his State of the Capital Address that it will continue to provide basic services to all residents. This includes efficient maintenance of traffic lights, repairing of potholes and sinkholes, the efficient operation and development of its bus services and 'the construction, tarring and resurfacing of roads across the vast landscape that is Tshwane' (Ramokgopa, 2016: 22). (An executive mayor is assigned the executive political leadership of the municipality). According to Findley and Ogbu (2011: [v]) townships have developed during the apartheid era before 1994 forcing people of different race groups to stay only in designated areas. Since the democratic elections of 1994 fragmented towns had to be integrated, placing an exceptionally high burden on municipalities. The City of Tshwane Metropolitan Municipality's by-laws had to be amended to cater for the integrated area covering \pm $6300 \mathrm{~km}^{2}$ to manage the extensive rural areas and the various informal settlements in terms of the Municipality's policies (City of Tshwane Metropolitan Municipality, s.a.: 1). The Executive Mayor of Tshwane noted that substantial funding will be needed in the near future to address ageing infrastructure that led to $25.4 \%$ water loss per annum for the City (Ramokgopa, 2016: 25). Thus, the integration of former segregated local authorities into one municipality increases the demand for services, but without any increase in the revenue sources of a municipality such as the Tshwane Metropolitan Municipality. In fact this is the case with all eight metropolitan municipalities.

\section{Future demands}

National government cannot be expected to assist municipalities indefinitely. Although municipalities experience challenges, they are required to do more with less and to re-evaluate their own resources or identify alternate funding sources (www.salga.org. za/). SALGA maintains that the solution to sustainability of municipalities lies mainly with the implementation of an alternate funding model, creating and instilling credibility and confidence in local government and building public sector competency and independence over time. The Minister of the SAPS claims that the solution to the continuous service delivery protests does not lie with the SAPS but with effective leadership and addressing service delivery issues and other developmental needs in the communities (Nhleko, 2015: v).

According to the South Africa, Republic (2015a: 5) Budget Review specific economic pressures will continue to result in less money being available for infrastructure. It postulates that year-on-year infrastructure will decline as well as a decline in the spending for at least the next three years. Therefore, it is important that all spheres of government 'get infrastructure right by providing value for money, prioritising investments that will have the greatest impact on growth and managing infrastructure projects more efficiently'.

The 2014-2019 MTSF reveals that more than R1 billion $(£ 1=\mathrm{R} 16)$ per year is spent on municipal support and capacity building. Municipalities are governed 'through a robust legislative and regulatory framework'. Strategies, policies, guidelines and programmes are available to support, monitor and intervene in the local sphere of government if necessary (South Africa, Republic, 2014e: 14; section 139, Constitution, 1996). It is maintained that what is needed is continuous improvement, innovative approaches, discipline and rigorous monitoring to ensure 
better results.

The FFC proposes that the reasons for municipalities' non-payment of debt to Eskom and Water Boards should be investigated; there should be consequences for bad management by municipalities and individuals that continuously do not adhere to the rules of the MFMA. Lasting solutions must be found for municipal debt problems and withholding of equitable share funding from municipalities should be a last resort since it seriously affects service delivery, especially to the poorest households (South Africa, Republic, 2015b: 17-18).

The poor state of municipal finance could be corrected through decisive political leadership that promotes the interest of residents and business instead of their own benefit (www.ratingsafrika.com). Municipalities must combat corruption, appoint managers with the necessary skills and experience as it is indeed a requirement in terms of section 56 of the MSysA. Their duties include the effective implementation of the budgetary processes and the requirement to practise financial discipline (Slabbert, 2016: 5). The Agency reports that the most financially sustainable municipalities are Hessequa in the Western Cape Province and KwaDukuza in KwaZulu Natal Province. These municipalities base their success on good financial policies and budgets that are based on long-term strategies. They have effective budgetary practices, strict control and excellent revenue collection.

It is essential that the design and management of each grant contribute to good practices in planning and maintenance.

Rewards must be created for municipalities that perform well and penalties for those that do not adhere to good practices (South Africa, Republic, 2014c: 18).

\section{Back-to-basics policy}

COGTA's back-to-basics policy focuses on uplifting the services provided by municipalities in the country. It highlights the need for standards, good practice across all municipalities, identifying key performance areas and monitoring and oversight. Municipalities must work towards creating decent living conditions for communities by developing fundable infrastructure plans, ensuring infrastructure maintenance and developing service standards. Good governance and public participation and sound financial management must be addressed. Filling municipal administrative positions with competent and committed employees and monitoring their performance are also crucial (South Africa, Republic, 2014b: 11-12).

COGTA identifies the responsibilities of the three spheres of government in ensuring sustainable and well-functioning municipalities. An Inter-Ministerial Committee on Service Delivery could ensure that the approach of all spheres of government towards local government service delivery is coordinated and that oversight over performance is increased. One of the measures is the establishment of a 'war room' and national monitoring system to track and intervene with regards to municipal performance. It also includes collective efforts to ensure that municipalities operate effectively and that political tensions and the pol- itical/administrative interface are managed effectively (South Africa, Republic, 2014b: 12).

\section{Conclusion}

It is evident from the above that provision of grants to municipalities does not necessarily ensure the sustainability of local government. The solution lies in the effective and efficient manner in which these funds are applied as well as stringent measures by National Treasury for those municipalities that revert to underutilisation or misuse of these funds, as well as maladministration 
and corruption.

Municipalities must take responsibility for adhering to the requirements of the MFMA to manage their budgets. They must address the Auditor-General's findings to constantly aim at improving their financial performance. Regular monitoring of municipal IDPs must take place to ensure that funding is allocated according to project plans and linked to performance and the budgets of the municipalities.

Municipalities should ensure that they have a sound billing system and must place high priority on the collection of revenue owed to them for services delivered. Accountability and severe consequences for non-performance of municipal employees must apply. Further to this, municipalities should use grant funding that is available for skills development to ensure better performance of municipal employees, management and councillors. However, the aim is ultimately that politicians and municipal officials will possess acceptable values to perform efficiently because they agree with the policies and practices. They want to act in accordance with the principles of good governance, transparency and responsibility to manage public resources in such a way that it will contribute to the sustainability of local government in the country.

\section{Declaration of conflicting interests}

The author(s) declared no potential conflicts of interest with respect to the research, authorship, and/or publication of this article.

\section{Funding}

The author(s) received no financial support for the research, authorship, and/or publication of this article.

\section{References}

City of Tshwane Metropolitan Municipality (s.a.) By-laws relating to the management and control of informal settlements. Available at: www.tshwane.gov.za (accessed 30 June 2016).

Clark J (2012) Fighting corruption: Treasury cuts funding to municipality. Available at: www.moneyweb.co.za/ (accessed 4 May 2016).

Eskom (s.a.) Company information overview. Available at: www.eskom.co.za/OurCompany (accessed 26 June 2016).

Evans J (2015) Rand water to help dry Bushbuckridge. Available at: www.news24. com (accessed 30 April 16).

Findley L and Ogbu L (2011) South Africa: From township to town. Available at: www. placesjournal.org/article/south-africa-from- township-to-town/ (accessed 27 June 2016).

KPMG (2014) Unpacking the national infrastructure development plan. Available at: www.sablog.kpmg.co.za/2014/03/unpacking- national-infrastructure-development-plan (accessed 27 April 16).

Madonsela TN (2013) Good governance: The key to sustainable service delivery. In: Presentation at the IMFO Audit \& Risk Indaba, Cape Town, 10 April 2013. Available at: www.pprotect. org/media_gallery/ (accessed 24 April 16).

Mahabir J and Mabena N (2015) Identifying the funding constraints in municipal capital investments. Available at: www.ffc.co.za

(accessed 23 April 2016).

Nhleko N (2015) Minister Nkosinathi Nhleko: South African police department budget vote 2015/16. THEME: Building a united front to help and protect communities. Available at: www.gov.za/speeches (accessed 26 April 2016).

Palmer I (2011) An assessment of the performance of district municipalities. Available at: pdg.co.za (accessed 30 April 2016). 
Ramokgopa K (2016) State of the capital address by the executive Mayor of Tshwane, Councillor Kgosientso Ramakgopa. Tshwane one nation: One capital. Advancing Tshwane Vision 2055. Available at: www.tshwane.gov. za (accessed 28 April 2016).

Schoeman N (2011) Fiscal performance and sustainability of local government in South Africa - An empirical analysis. Available at: www.econtsa.org/ (accessed 27 April 2016).

Seerane C (2016) State of the city address presented by Mogale City local municipality executive Mayor, Councillor Calvin Seerane. Available at: www.mogalecity.gov.za (accessed 29 April 2016).

Slabbert A (2016) 60\% of key municipalities in financial trouble - Ratings Afrika. Available at: www.moneyweb.co.za (accessed 4 May 2016).

South Africa, Republic (1996) Constitution of the Republic of South Africa. Pretoria: Government Printer.

South Africa, Republic (1997) Intergovernmental Fiscal Relations Act 97. Pretoria: Government Printer.

South Africa, Republic (1998a) White Paper on Local Government, March. Pretoria: Government Printer.

South Africa, Republic (1998b) Local Government: Municipal Structures Act 117. Pretoria: Government Printer.

South Africa, Republic (2000) Local Government: Municipal Systems Act 32. Pretoria: Government Printer.

South Africa, Republic (2003) Local Government: Municipal Finance Management Act 56. Pretoria: Government Printer.

South Africa, Republic (2007) Municipal Fiscal Powers and Functions Act 12 and Regulations. Pretoria: Government Printer.

South Africa, Republic (2009) Money Bills Amendment Procedures and Related Matters Act 9. Pretoria: Government Printer.

South Africa, Republic (2011) National Development Plan: Vision 2030. Pretoria: The Presidency.

South Africa, Republic (2012) National treasury. Discussion Paper 1. Proposed principles and objectives of the local government equitable share formula. Available at: www.ffc.co.za (accessed 23 April 2016).

South Africa, Republic (2014a) Auditor- General: Consolidated general report on the audit outcomes of local government. MFMA. 2013-14. Available at: www.agsa.co.za (accessed 24 April 2016).

South Africa, Republic (2014b) Cooperative governance and traditional affairs. The Presidential Local Government Summit. BACK TO BASICS. Serving our communities better. Available at: www.cogta.gov.za (accessed 20 April 2016).

South Africa, Republic (2014c) National treasury. Review of local government infrastructure grants. Recommendations for reform. Available at: www.ffc.co.za (accessed 4 May 2016).

South Africa, Republic (2014d) South African government. Water and sanitation. 2014. Available at: www.gov.za/about-sa/water-

affairs (accessed 26 July 2016).

South Africa, Republic (2014e) The presidency. Department: Planning, monitoring and evaluation. Mediumterm strategic framework (MTSF) 2014-2019. Available at: www. dpme.gov.za (accessed 23 April 2016).

South Africa, Republic (2015a) National treasury. Budget review: 2015. Available at: www. treasury.gov.za (accessed 20 April 2016).

South Africa, Republic (2015b) National Treasury. Website annexure to the 2015 budget review. Explanatory memorandum to the division of revenue. Available at: www. treasury.gov.za (accessed 20 April 2016).

South Africa, Republic (2015c) Financial and Fiscal Commission. Withholding of LES allocations: Presentation to the standing committee on appropriations. 29 July 2015. Available at: www.ffc.co.za (accessed 26 April 2016).

South Africa, Republic (2015d) Financial and fiscal commission. Financial and fiscal commission on submission for the 2016/17 division of revenue. Available at: www.gov.za/ speeches/submission-201617-division-revenue- 1-jun-2015-0000 (accessed 27 April 2016).

South Africa, Republic (2016a) Division of Revenue Act 3. Pretoria: Government Printer.

South Africa. Republic (2016b) National treasury. Budget review. Available at: www.treas- ury.gov.za (accessed 20 April 2016). 
South Africa, Republic (2016c) National treasury annexure: Summary of allocation to local government. Available at: www.treas- ury.gov.za (accessed 30 April 2016).

South Africa, Republic (s.a.) Auditor General. The role of the auditor-general. Auditing to build public confidence. Available at: www. agsa.co.za/Portals/0/Audit101/The_role_of_the_Auditor_General.pdf (accessed 4 May 2016).

South Africa, Republic (s.a.) National Treasury. Financial management and MFMA implementation. Available at: www.treasury.gov. za (accessed 1 May 2016).

South Africa, Republic (s.a.) Department of Environmental Affairs. National framework for sustainable development. Available at: www.environment.gov.za (accessed 30 April 2016).

South African Local Government Association (2011) Division of revenue Act Brochure 2011-2012. Available at: www.salga.org.za (accessed 20 April 2016).

South African Local Government Association (2015a) Ensuring the viability and sustainability of municipalities and improving their credit worthiness - An alternative funding model (doing the right thing for municipalities). Available at: www.salga.org.za/ (accessed 26 April 2016).

South African Local Government Association (2015b) SALGA response to National Treasury withholding equitable share allocations to municipalities. Available at: www. gov.za/speeches/ (accessed 4 May 2016).

Thornhill C (2011) Spheres of government. Contributions to sustainable service delivery. African Journal of Public Affairs 4(1): 45-57.

Thornhill C and Cloete JJN (2014) South African municipal government and Administration, 2nd ed. Pretoria: Van Schaik Publishers.

www.sacities.net/ (accessed 3 July 2016).

www.ffc.gov.za/ (accessed 28 April 2016).

www.ratingsafrika.com (accessed 4 May 2016). 